\title{
Sintesis dan Pencirian Getah Asli Cecair Terhidrogen untuk Adunan Polimer
}

(Synthesis and Characterization of Hydrogenated Liquid Natural Rubber for Polymer Blending)

\author{
MuHAMMAd JEFRI MOHD YusOF, IBRAHIM ABDUllaH \& Siti FAIRUS M YuSOFF*
}

\section{ABSTRAK}

Sistem hidrazin hidrat/hidrogen peroksida $\left(\mathrm{HH}_{\mathrm{H}} \mathrm{H}_{2} \mathrm{O}_{2}\right)$ digunakan untuk menjana sumber hidrogen bagi tujuan penghidrogenan getah asli cecair (LNR) melalui penghasilan diimida. Spesies diimida yang terhasil akan membekalkan sumber hidrogen kepada ikatan karbon ganda dua dalam rantai polimer LNR. Getah asli cecair terhidrogen (HLNR) yang terhasil menunjukkan ciri lebih tahan suhu berbanding LNR. Suhu degradasi HLNR didapati meningkat pada $435^{\circ} \mathrm{C}$ berbanding LNR iaitu pada $381^{\circ} \mathrm{C}$. HLNR seterusnya dijadikan pengserasi dalam penghasilan adunan polimer polistirena/ getah asli, PS/NR/HLNR (60/35/5). Kekuatan regangan dan impak PS/NR masing-masing meningkat sebanyak $70.7 \%$ dan $149.6 \%$ setelah HLNR ditambah sebagai pengserasi dalam adunan. Beberapa pemerhatian morfologi melalui mikroskop optik dan SEM turut menyokong kesan penyerasian adunan PS/NR dengan HLNR.

Kata kunci: Adunan polimer; diimida; penghidrogenan; pengserasi; spektroskopi

\section{ABSTRACT}

Hydrazine hydrate/hydrogen peroxide system $\left(\mathrm{HH} / \mathrm{H}_{2} \mathrm{O}_{2}\right)$ was used in this study to generate hydrogen source for the hydrogenation of LNR via production of diimide. Those diimide species supplied hydrogen source to be bonded with the double bonds of LNR. HLNR exhibited improved thermal properties than LNR. The degradation temperature of HLNR was found to be higher at $435^{\circ} \mathrm{C}$ than LNR that was only at $381^{\circ} \mathrm{C}$. HLNR was then used as a compatibilizer in the polymer blending of polystyrene/natural rubber, PS/NR/HLNR (60/35/5). The tensile strength and impact strength of PS/NR were increased $70.7 \%$ and $149.6 \%$, respectively, when HLNR was added into the blends. Several morphological observations through optical microscope and SEM supported the compatibilizing effect of HLNR in PS/NR blending.

Keywords: Compatibilizer; diimide; hydrogenation; polymer blending; spectroscopy

\section{PENGENALAN}

Getah asli cecair (LNR) ditakrifkan menurut laporan United Nations Industrial Development Organization (UNIDO) sebagai getah asli kering atau getah asli yang boleh dituang atau dipam tanpa penggunaan pelarut dan mempunyai kelikatan di bawah 1500 poise pada suhu bawah $100^{\circ} \mathrm{C}$ (Azhar et al. 2017). LNR juga boleh didefinisikan sebagai getah asli yang mempunyai mikrostruktur yang sama dan berat molekul lebih rendah daripada $10^{5}$ (Chumeka et al. 2014).

Penghidrogenan adalah tindak balas penambahan hidrogen ke dalam ikatan karbon tidak tepu (Cao et al. 2015a). Kaedah ini berguna untuk meningkatkan ketahanan polimer yang mengandungi kumpulan berfungsi diena terhadap degradasi oksidatif, radiasi dan suhu (Ai et al. 2017). Rantaian polimer LNR yang lebih pendek dijangka dapat memudahkan tindak balas penghidrogenan ikatan ganda dua unit isoprena getah (Jamaluddin et al. 2016). Ciri-ciri ini penting untuk pembuatan produk berasaskan getah yang lebih stabil (Wu et al. 2014).

Penghidrogenan getah asli yang dilakukan oleh Samran et al. (2005) mendapati bahawa peratus penukaran penghidrogenan yang tertinggi adalah $38.0 \%$ dalam bentuk lateks. Kajian yang sama juga digunakan untuk getah poliisoprena sintetik dalam bentuk lateks yang mencapai peratusan penghidrogenan tertinggi sebanyak $22.9 \%$. Berat molekul getah asli yang tinggi dan sebatian semula jadi dalam getah asli menyukarkan tindak balas berlaku kerana penghidrogenan terhad untuk berlaku di permukaan partikel sahaja (Liu et al. 2016).

Dalam kajian ini, LNR diturunkan menggunakan sistem $\mathrm{HH} / \mathrm{H}_{2} \mathrm{O}_{2}$. Kaedah tanpa mangkin ini lebih menjadi tumpuan para penyelidik kerana tindak balas dilakukan menggunakan peralatan makmal yang ringkas dalam keadaan suhu yang sederhana dan pada tekanan atmosfera, tanpa penggunaan mangkin daripada logam peralihan. Kaedah penghasilan sumber diimida untuk penghidrogenan ini diperkenalkan oleh Wideman (1984) dan terus dikembangkan untuk mencapai hasil yang optimum oleh para penyelidik. Penggunaan medium akues dalam eksperimen ini memudahkan penyingkiran pelarut organik yang bertoksik dalam tindak balas (Joumaa et al. 2017). Simma et al. (2009) mencadangkan mekanisme penghasilan sumber diimida dan proses penghidrogenan poliisoprena seperti ditunjukkan dalam Rajah 1.

Kajian terhadap polimer baru yang dihasilkan melalui proses adunan polimer semakin berkembang sejak tiga dekad yang lalu (Ramarad et al. 2015). Adunan antara 


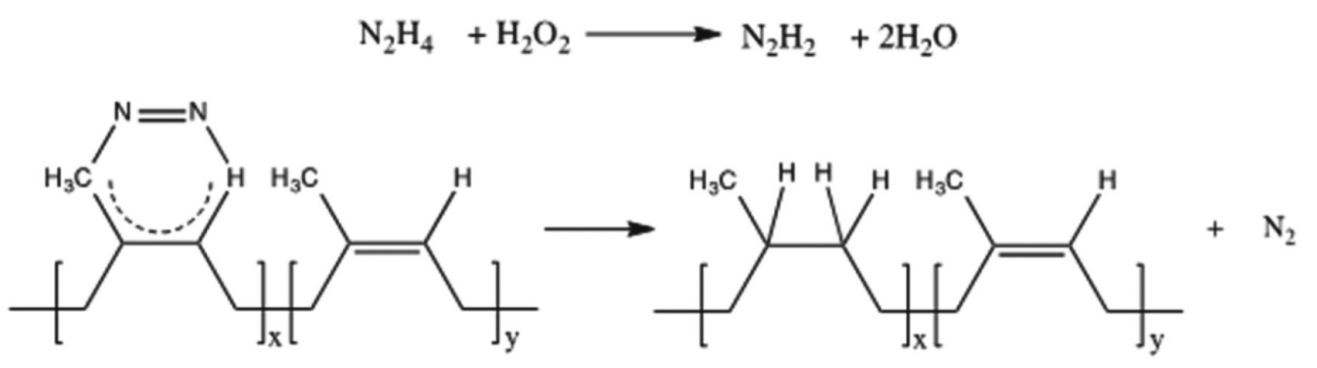

RAJAH 1. Penghasilan diimida dan proses penghidrogenan poliisoprena seperti yang dicadangkan oleh Simma et al. (2009)

polimer sintetik dan polimer semula jadi boleh menghasilkan bahan baru dengan ciri yang ditambah baik berbanding komponen berasingan sebelum diadunkan. Polimer baru yang terbentuk daripada adunan polimer semula jadi dan sintetik bakal memiliki ciri bioserasi, mekanik dan terma yang baik yang boleh digunakan dalam pelbagai bidang khususnya aplikasi bioperubatan dan kegunaan industri (Reddy et al. 2015).

Orathai et al. (2010) menggunakan getah asli terubah suai dengan stirena sebagai pengserasi dalam adunan lateks buangan getah asli/polistirena dan mendapati bahawa kekuatan regangan dan pemanjangan pada pemutusan produk mereka meningkat. Kelekatan antara muka fasa lateks buangan getah asli dan fasa polistirena didapati meningkat dan kesebaran adunan menjadi lebih baik apabila dilihat menerusi mikrograf digital. Sifat terma adunan polimer juga didapati meningkat apabila pengserasi digunakan. Mohamad et al. (2014) mengkaji sifat terma adunan getah asli/EPDM dengan menggunakan getah asli terepoksida sebagai pengserasi dan menyimpulkan bahawa sifat terma keseluruhan adunan meningkat setelah mendapati bahawa kehilangan berat adunan lebih rendah berbanding kehilangan berat homopolimer sebelum diadunkan.

Dalam kajian ini, produk terhidrogen (HLNR) dijadikan sebagai pengserasi dalam adunan polistirena (PS) dengan getah asli (NR). PS memiliki ciri-ciri yang berguna seperti keras, mudah diproses dan dihasilkan dengan kos yang rendah tetapi PS mempunyai kekuatan hentaman yang rendah dan mudah tergedrasi dengan bahan kimia seperti keton dan eter pada suhu bilik (Blanco et al. 2014). Sifat elastik NR dapat menyumbang kepada kekuatan regangan produk yang lebih tinggi setelah diadunkan dengan PS. HLNR memiliki berat molekul yang lebih rendah berbanding LNR dan kelikatan yang berbeza apabila struktur LNR yang tidak tepu bertukar tepu. Ciri ini dijangka dapat menjadikan serakan antara PS dan NR menjadi lebih seragam apabila HLNR digunakan sebagai pengserasi dalam adunan PS/NR.

\section{BAHAN DAN KAEDAH}

\section{BAHAN}

Getah asli (SMR L) diperoleh daripada Lembaga Getah Malaysia (LGM). Pelarut metanol dan toluena dibeli daripada RM Chemicals (Himachal Pradesh, India). Merah jambu bengal, metilina biru, minyak silikon, natrium dodesil sulfat (SDS), $\mathrm{HH}$ dan $\mathrm{H}_{2} \mathrm{O}_{2}$ dibeli daripada SigmaAldrich (Missouri, USA). Semua pelarut dan bahan tindak balas dalam eksperimen ini digunakan seperti diterima.

\section{PENYEDIAAN LNR}

Potongan kiub kecil getah asli sebanyak 500 g direndam dalam 1 L larutan toluena. Selepas semalaman, getah membengkak. Beberapa titisan pewarna merah jambu bengal dan metilina biru diletakkan bersama metanol sebagai pelarut dan dikacau sehingga sebati. Getah dikacau berterusan di bawah penataan cahaya yang malar pada kadar 10-15 putaran seminit selama lebih kurang tujuh hari. Sampel kemudiannya diempar untuk menghasilkan dua lapisan getah yang mempunyai berat molekul berbeza. Lapisan getah di atas yang lebih cair digunakan kerana memiliki produk gumpalan yang lebih sedikit.

\section{PENURUNAN DIIMIDA LNR}

LNR ditimbang dalam kelalang kaca berleher tiga sebanyak 5 g. Kemudian, $20 \mathrm{~mL}$ toluena dimasukkan dan dikacau sebati. Sebanyak $50 \mathrm{~mL}$ air suling, $0.1 \mathrm{~g}$ surfaktan dan beberapa titisan minyak silikon dimasukkan ke dalam campuran tersebut dan dikacau selama 30 min di atas plat panas dengan suhu sistem digunakan adalah $60^{\circ} \mathrm{C}$. Proses pengacauan adalah berterusan sepanjang eksperimen dijalankan. HH kemudian dititiskan dalam tempoh masa 30 min. Serbuk asid borik ditimbang sebanyak $1.5 \mathrm{~g}$ kemudian dilarutkan dalam $5 \mathrm{~mL}$ air suling. Sebanyak $40 \mathrm{~mL} \mathrm{H}_{2} \mathrm{O}_{2}$ dimasukkan ke dalam larutan asid borik tersebut dan dikacau sebati. Larutan $\mathrm{H}_{2} \mathrm{O}_{2}$ dan asid borik dimasukkan secara titisan pada kadar $0.083 \mathrm{~mL} / \mathrm{min}$ menggunakan corong penitis. Produk terhasil dimendakkan dalam metanol dan dibilas dengan air suling sebelum dikeringkan dalam relau vakum.

\section{PENYEDIAAN ADUNAN PS/NR}

Adunan PS/NR disediakan dengan kaedah lebur-campur dengan penggunaan HLNR sebagai pengserasi pada nisbah PS/NR/HLNR sebanyak 60:35:5. Pelet polistirena dimasukkan ke dalam corong dan dikisar selama 5 min diikuti dengan 
getah asli selama 5 min. Akhir sekali, HLNR dimasukkan dan dikisar selama 5 min. Kesemua sampel dikisar pada kelajuan $50 \mathrm{rpm}$ dan suhu $150^{\circ} \mathrm{C}$. Sampel kemudiannya dileburkan di atas plat acuan pada suhu $150^{\circ} \mathrm{C}$ selama 5 min pada tekanan $70 \mathrm{~kg} / \mathrm{cm}^{2}$. Sampel dibiarkan sejuk pada suhu persekitaran dalam 15 min sebelum disimpan pada suhu bilik selama 24 jam.

\section{PENCIRIAN PRODUK}

Produk yang terhasil selepas penurunan diimida dicirikan menggunakan spektroskopi FTIR dan NMR. Untuk analisis FTIR (spektrometer Perkin Elmer/BX, USA), sampel diletakkan di atas kristal ATR dan spektrum FTIR diukur. Spektroskopi NMR (spektroskopi JEOL JNM-ECP 400 MHz, Jepun) digunakan bagi mengkaji persekitaran struktur kimia produk yang terhasil. Sampel dilarutkan dalam klorofom $\left(\mathrm{CDCl}_{3}\right)$ dan kemudiaannya dianalisis. Suhu penguraian sampel diukur menggunakan penganalisis termogravimetrik (TGA/SDTA 851e, Mettler Toledo, Switzerland). Sifat tensil adunan PS/NR dikaji berdasarkan protokol ASTM D 412-68 dan dikira menggunakan Mesin Ujian Universal (Instron/5566, Singapura) pada kadar regangan $10 \mathrm{~mm} / \mathrm{min}$. Ujian hentaman dikendalikan berdasarkan protokol ASTM D256 menggunakan Sistem Hentaman (Model IT504/Model 104/Tinius Olsen, USA). Akhir sekali, morfologi adunan PS/NR diperhatikan di bawah mikroskop optik pada pembesaran $50 \times$ dan melalui mikroskop imbasan elektron (SEM) (JEOL JSM-6400) pada pembesaran $1000 \times$ dan $15 \mathrm{kV}$ pecutan voltan.

\section{HASIL DAN PERBINCANGAN}

\section{PENCIRIAN STRUKTUR LNR DAN HLNR}

Spektroskopi FTIR dan NMR digunakan untuk membuktikan struktur HLNR. Rajah 2 menunjukkan spektrum FTIR bagi LNR dan HLNR. HLNR ini disintesis pada suhu $50^{\circ} \mathrm{C}$ selama 6 jam dalam radas tindak balas yang mengandungi $\mathrm{HH}\left(6 \times 10^{-}\right.$ $\left.{ }^{3} \mathrm{mmol}\right), \mathrm{H}_{2} \mathrm{O}_{2}(1.71 \mathrm{~mol})$ dan asid borik $\left(2 \times 10^{-4} \mathrm{mmol}\right)$. Puncak pada $1664 \mathrm{~cm}^{-1}$ (Rajah 2(a)) mewakili regangan $\mathrm{C}=\mathrm{C}$. Keamatan yang sedikit pada isyarat dalam spektrum
HLNR menunjukkan bahawa penghidrogenan telah berlaku yang disebabkan oleh pengurangan bilangan ikatan $\mathrm{C}=\mathrm{C}$ (Rajah 2(b)).

Peratus penghidrogenan dikira berdasarkan spektrum ${ }^{1} \mathrm{H}$ NMR getah asli cecair terhidrogen (Cao et al. 2015b: Kongparakul et al.2011). Puncak spektrum yang diperhatikan untuk pengiraan peratusan penghidrogenan adalah pada kawasan olefinik, $\beta$ (5.3 ppm) dan alifatik, $\alpha$ (0.8 hingga $2.2 \mathrm{ppm}$ ). Formula yang digunakan adalah seperti yang ditunjukkan dalam (1) (Kongparakul et al. 2011).

$$
\text { Peratus penghidrogenan, }(\%)=\frac{\alpha-7 \beta}{\alpha+3 \beta} \times 100 \text {. }
$$

Rajah 3 menunjukkan spektrum ${ }^{1} \mathrm{H}$ NMR bagi LNR dan HLNR. Pengurangan keamatan puncak pada kawasan olefinik 5.2 ppm menunjukkan bahawa terdapat pengurangan unit ikatan karbon ganda dua dan penambahan unit tepu pada kawasan alifatik 0.8 hingga 2.2 ppm (Rajah 3(b)). Berdasarkan integrasi luas permukaan spektrum tersebut, peratusan penghidrogen yang dikira adalah sebanyak 91.2\%. Struktur HLNR dapat juga ditentukan menggunakan spektrum ${ }^{13} \mathrm{C}$ NMR seperti yang ditunjukkan pada Rajah 4. Puncak 124.9 ppm dan 135.1 ppm yang terdapat pada spektrum LNR berkurang pada spektrum HLNR menunjukkan bahawa berlaku pengurangan unit ikatan karbon ganda dua. Terdapat tiga puncak baru muncul pada $19.5,32.8$, dan $37.1 \mathrm{ppm}$ pada spektrum HLNR membuktikan bahawa penghidrogenan berlaku pada karbon metil, metilin dan methin pada unit tepu. Kehadiran puncak yang merujuk kepada isyarat daripada karbon tidak tepu pada LNR menunjukkan bahawa penghidrogenan tidak berlaku sepenuhnya.

\section{KESTABILAN TERMA HLNR}

Analisis TGA digunakan untuk mengetahui sifat terma getah asli cecair terhidrogen. Suhu penguraian sampel terpilih ditentukan dengan menggunakan TGA dan hasilnya adalah seperti yang terdapat pada Rajah 5. Getah asli cecair terhidrogen mula terurai pada suhu $380^{\circ} \mathrm{C}$. Penguraian lengkap berakhir pada suhu $422^{\circ} \mathrm{C}$ dan $435^{\circ} \mathrm{C}$ masingmasing untuk produk dengan darjah penghidrogenan

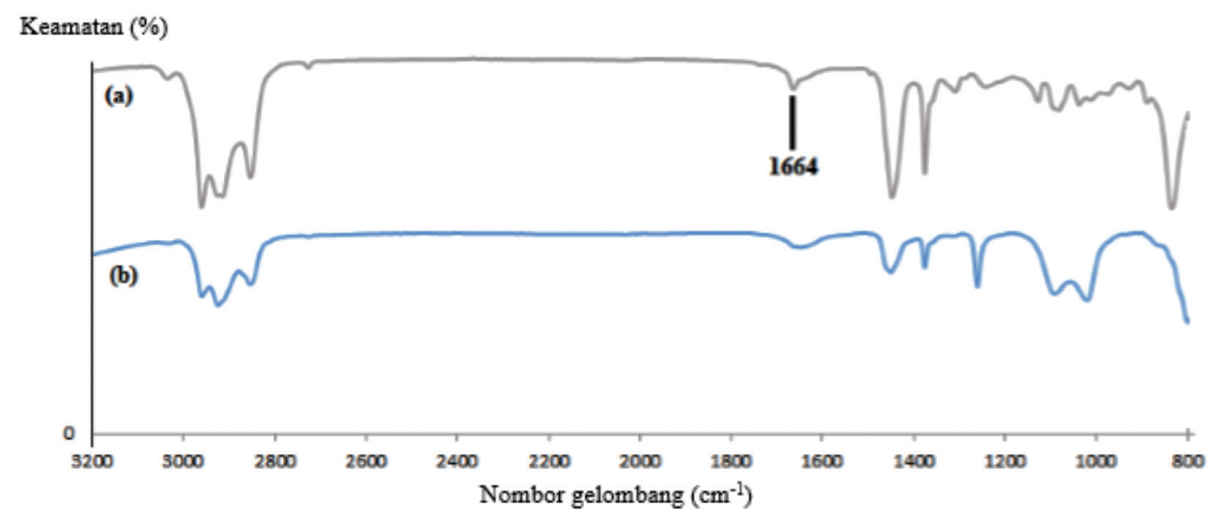




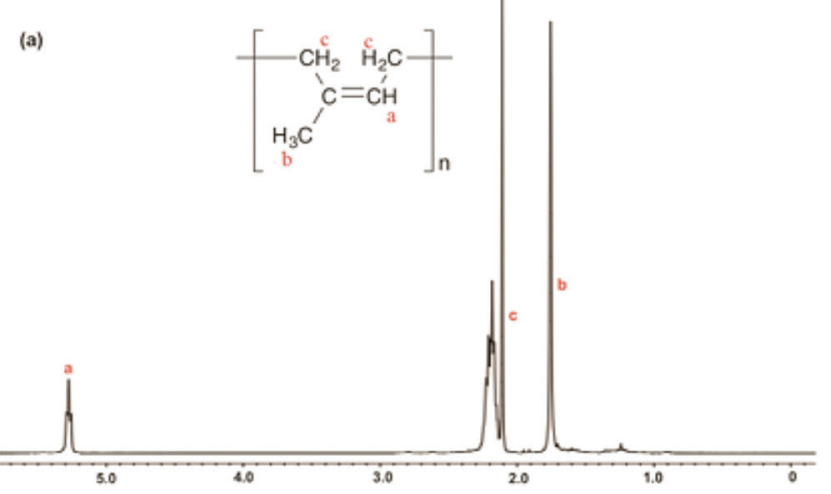

(b)
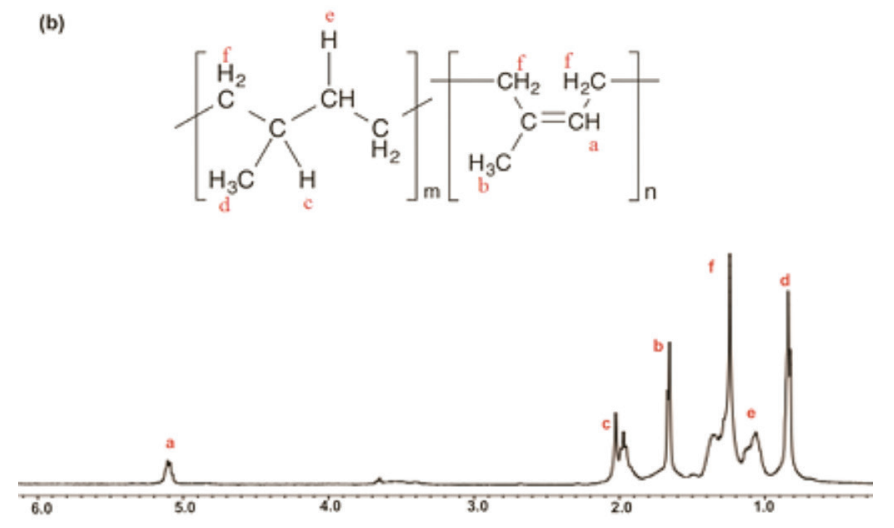

RAJAH 3. Spektrum ${ }^{1} \mathrm{H}$ NMR untuk (a) LNR dan (b) HLNR

(a)

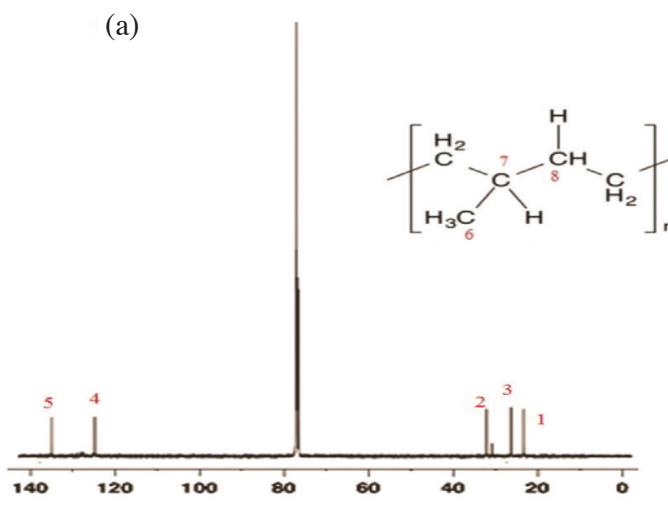

(b)<smiles>CCC=C(C)CCC</smiles>

RAJAH 4. Spektrum ${ }^{13} \mathrm{C}$ NMR untuk (a) LNR dan (b) HLNR

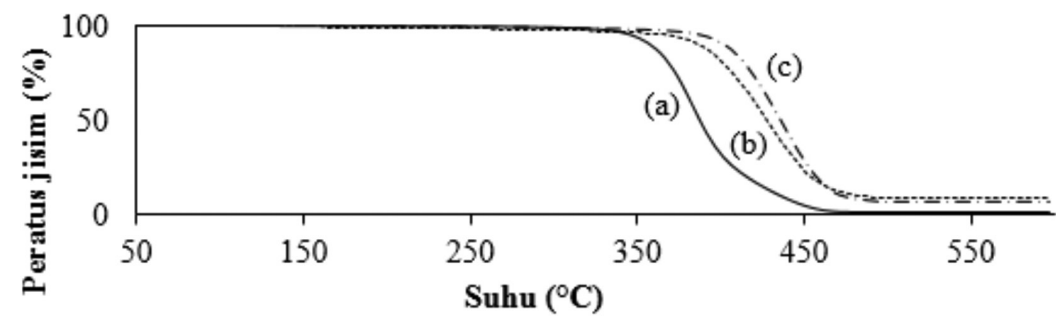

RAJAH 5. Termogram untuk (a) LNR (b) 50.1\% HLNR dan (c) 91.2\% HLNR 
sebanyak $50.1 \%$ dan $91.2 \%$. Suhu penguraian bagi NR dan LNR adalah $300^{\circ} \mathrm{C}$ dan $340^{\circ} \mathrm{C}$ (Ahmad et al. 2016). Hal ini membuktikan bahawa sifat terma HLNR adalah meningkat berbanding LNR.

Peningkatan suhu penguraian pada getah asli cecair terhidrogen disebabkan oleh pengurangan unit ikatan karbon ganda dua yang telah ditambah dengan unit tepu semasa penghidrogenan. Penghidrogenan mampu meningkatkan kestabilan terma getah dengan menukarkan ikatan $\pi$ yang lemah kepada ikatan $\sigma \mathrm{C}-\mathrm{H}$ yang lebih kuat (Simma et al. 2009). Kajian kestabilan terma komposit getah asli oleh Zhang et al. (2014) turut menunjukkan suhu penguraian getah stirina/butadiena (SBR) meningkat apabila nanokomposit SBR diisi dengan kaolinit yang berperanan mengurangkan unit tidak tepu dalam SBR.

\section{ADUNAN PS/NR}

Aplikasi HLNR digunakan dalam adunan PS/NR (60/40) sebagai pengserasi. Kajian terhadap sifat mekanik dan morfologi adunan polimer yang terhasil dilakukan bagi melihat kesan pengserasian oleh HLNR.

\section{SIFAT MEKANIK}

Kekuatan regangan dan tenaga hentaman adunan PS/ NR dengan pengserasi yang berbeza adalah seperti yang ditunjukkan pada Jadual 1. Penambahan HLNR telah mempengaruhi kekuatan regangan dan tenaga hentaman adunan. HLNR sebagai pengserasi membantu dalam meningkatkan kelekatan antara fasa getah dan fasa polistirena. Daya tegangan antara muka dikurangkan dan interaksi antara fasa dalam matriks ditingkatkan oleh pengserasi (Zolali \& Favis 2017). Taburan fasa yang homogen (Jose et al. 2016) telah diperoleh apabila HLNR digunakan sebagai pengserasi yang menyumbang kepada peningkatan kualiti adunan PS/NR yang terhasil.

\section{MORFOLOGI}

Rajah 6 menunjukkan mikrograf optik bagi adunan PS/ NR dengan jenis-jenis pengserasi yang digunakan. Fasa serakan PS dan NR bertambah baik apabila pengserasi digunakan. Hal ini juga membuktikan bahawa serakan dalam adunan meningkat apabila pengserasi digunakan

JADUAL 1. Sifat mekanik adunan PS/NR

\begin{tabular}{cccc}
\hline Pengserasi & \% Penghidrogenan & Kekuatan regangan, MPa & Tenaga hentaman, $\mathrm{kJ} / \mathrm{m}^{2}$ \\
\hline- & - & 3.38 & 2.94 \\
LNR & - & 3.90 & 3.43 \\
HLNR 1 & 50.1 & 4.51 & 5.68 \\
HLNR 2 & 91.2 & 5.77 & 7.34 \\
\hline
\end{tabular}

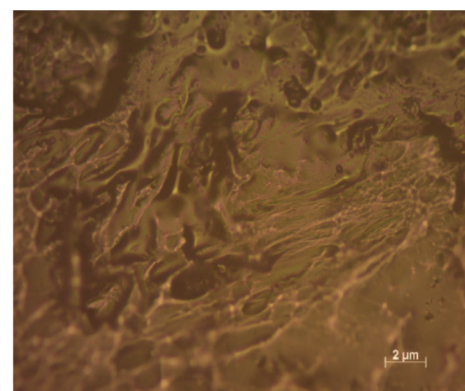

(a)

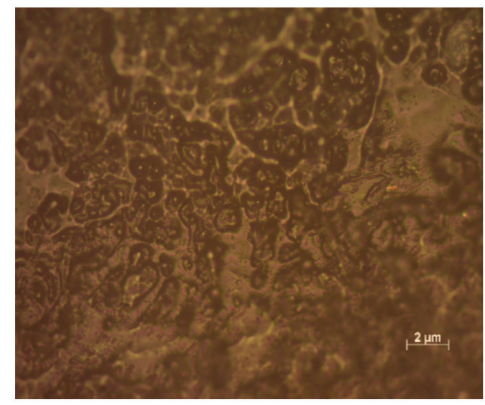

(c)

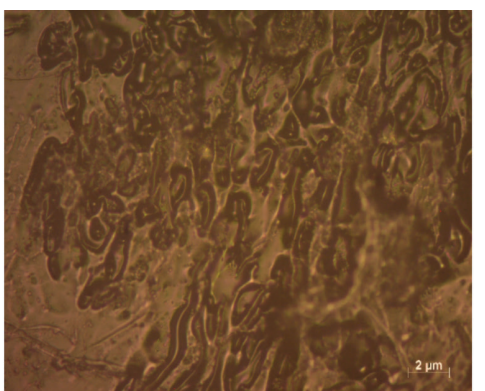

(b)

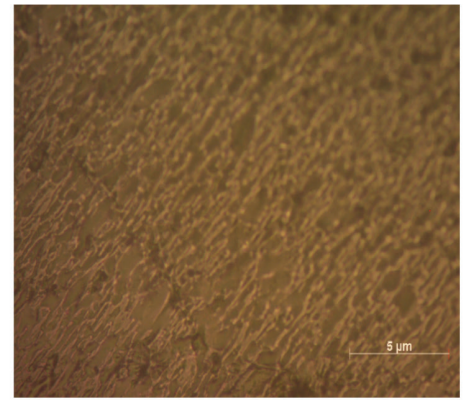

(d)

RAJAH 6. Mikrograf optik (50x) untuk adunan PS/NR (a) tanpa pengserasi dan menggunakan pengserasi (b) LNR (C) $50.1 \%$ HLNR (d) $91.2 \%$ HLNR 


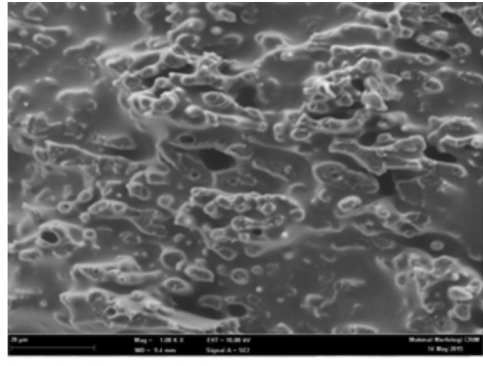

(a)

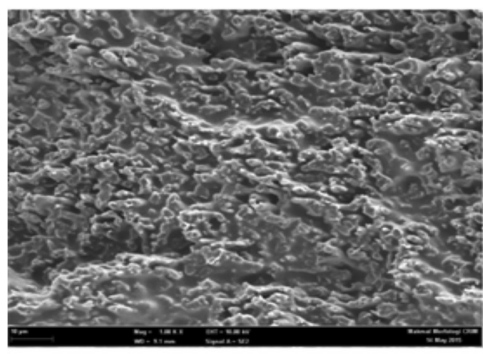

(c)

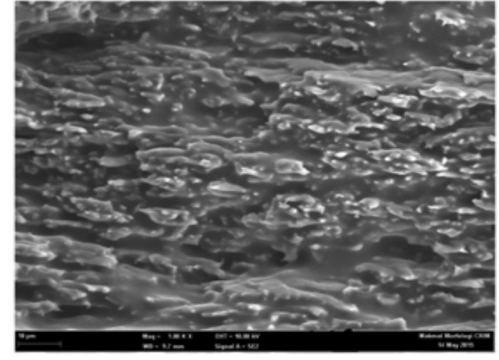

(b)

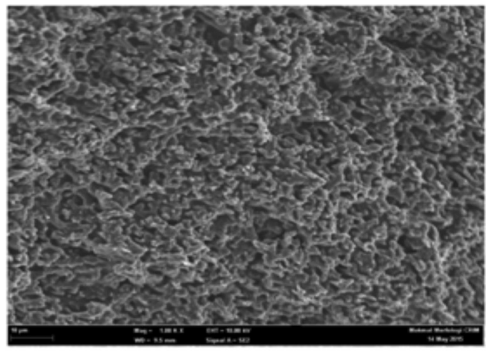

(d)

RAJAH 7. Mikrograf SEM (1000x) untuk adunan PS/NR (a) tanpa pengserasi dan menggunakan pengserasi (b) LNR (C) 50.1\% HLNR (d) $91.2 \%$ HLNR

terutamanya apabila HLNR dengan peratus penghidrogenan yang lebih tinggi digunakan.

Saiz partikel adunan PS/NR didapati berkurang pada penggunaan pengserasi HLNR dengan penghidrogenan yang lebih tinggi berbanding saiz partikel adunan PS/NR tanpa pengserasi. Hal ini dapat dilihat melalui mikrograf SEM pada Rajah 7. Penambahan HLNR ke dalam adunan menyumbang kepada taburan saiz partikel yang lebih seragam. Kelekatan antara partikel PS dan NR berjaya ditingkatkan sekaligus meningkatkan kekuatan regangan dan kekuatan hentaman (Effah et al. 2017). Sifat morfologi adunan juga bertambah baik setelah perbezaan fasa antaramuka PS dan NR dikurangkan oleh pengserasi.

\section{KESIMPULAN}

Diimida yang dihasilkan dari sistem $\mathrm{HH} / \mathrm{H}_{2} \mathrm{O}_{2}$ berpotensi untuk menjadi sumber hidrogen bagi tujuan penghidrogenan. Pencirian FTIR dan NMR membuktikan penghidrogenan telah berlaku dan peratusan penghidrogenan dapat dikira menggunakan integrasi luas kawasan olefinik dan alifatik spektrum ${ }^{1} \mathrm{H}$ NMR. Sifat terma HLNR didapati meningkat berbanding LNR seperti ditunjukkan melalui analisis TGA iaitu daripada suhu penguraian $340^{\circ} \mathrm{C}$ kepada $380^{\circ} \mathrm{C}$. Adunan PS/NR yang mengandungi HLNR sebagai pengserasi memiliki sifat mekanik yang lebih baik. Serakan partikel PS dan NR adalah lebih baik dalam kehadiran HLNR yang dibuktikan melalui mikroskop optik dan mikrograf SEM.

\section{PENGHARGAAN}

Para penulis ingin mengucapkan terima kasih kepada Pusat Penyelidikan dan Pengurusan Instrumentasi (CRIM), Universiti Kebangsaan Malaysia (UKM) dan Fakulti Sains dan Teknologi, UKM atas sokongan dan kemudahan yang diberikan. Sekalung penghargaan juga kepada UKM khususnya di atas dana geran GUP-2015-020 dan FRGS/1/2016/STG01/UKM/02/04.

\section{RUJUKAN}

Ahmad, N., Abnisa, F. \& Daud, W.M.A.W. 2016. Potential use of natural rubber to produce liquid fuels using hydrous pyrolysis-a review. RSC Advances 6(73): 68906-68921.

Ai, C., Gong, G., Zhao, X. \& Liu, P. 2017. Macroporous hollow silica microspheres-supported palladium catalyst for selective hydrogenation of nitrile butadiene rubber. Journal of the Taiwan Institute of Chemical Engineers 77: 250-256.

Azhar, N.H.A., Rasid, H.M. \& Yusoff, S.F.M. 2017. Epoxidation and hydroxylation of liquid natural rubber. Sains Malaysiana 46(3): 485-491.

Blanco, I., Abate, L., Bottino, F.A. \& Bottino, P. 2014. Thermal behaviour of a series of novel aliphatic bridged polyhedral oligomeric silsesquioxanes (POSSs)/polystyrene (PS) nanocomposites: The influence of the bridge length on the resistance to thermal degradation. Polymer Degradation and Stability 102: 132-137.

Cao, P., Ni, Y., Zou, R., Zhang, L. \& Yue, D. 2015a. Enhanced catalytic properties of rhodium nanoparticles deposited on chemically modified $\mathrm{SiO}_{2}$ for hydrogenation of nitrile butadiene rubber. RSC Advances 5(5): 3417-3424.

Cao, P., Wu, M.,Zou, R., Zhang, L. \& Yue, D. 2015b.A ternary Rh complex catalyst highly active and stable in the hydrogenation of acrylonitrile-butadiene rubber. New Journal of Chemistry 39(3): 1583-1586.

Chumeka, W., Pasetto, P., Pilard, J.F. \& Tanrattanakul, V. 2014. Bio-based triblock copolymers from natural rubber and poly (lactic acid): Synthesis and application in polymer blending. Polymer 55(17): 4478-4487.

Effah, B., van Reenen, A. \& Meincken, M. 2017. Mechanical properties of wood-plastic composites made from various wood species with different compatibilisers. European 
Journal of Wood and Wood Products. https://doi.org/10.1007/ s00107-017-1186-7.

Jamaluddin, N., Yusof, M.J.M., Abdullah, I. \& Yusoff, S.F.M. 2016. Synthesis, characterization, and properties of hydrogenated liquid natural rubber. Rubber Chemistry and Technology 89(2): 227-239.

Jose, S., Parameswaranpillai, J., Francis, B., Aprem, A.S. \& Thomas, S. 2016. Thermal degradation and crystallization characteristics of multiphase polymer systems with and without compatibilizer. Aims Materials Science 3(3): 11771198

Joumaa, A., Chen, S., Vincendeau, S., Gayet, F., Poli, R. \& Manoury, E. 2017. Rhodium-catalyzed aqueous biphasic hydrogenation of alkenes with amphiphilic phosphinecontaining core-shell polymers. Molecular Catalysis 438: 267-271

Kongparakul, S., Ng, F.T.T. \& Rempel, G.L. 2011. Methatesis hydrogenation of natural rubber latex. Journal of Applied Catalysis 405: 129-136.

Liu, J., Tian, X.H., Sun, J.Y., Wang, S.Y. \& Duan, J.C. 2016. Mechanical properties and thermal resistance of natural rubber nanocomposite reinforced with quaternized polyvinyl alcohol/silica nanoclusters. Journal of Nano Research 43: 46-56.

Mohamad, N., Yaakub, J., Abd Razak, J., Yaakob, M.Y., Shueb, M.I. \& Muchtar, A. 2014. Effects of epoxidized natural rubber (ENR-50) and processing parameters on the properties of NR/EPDM blends using response surface methodology. Journal of Applied Polymer Science 131(17): DOI: 10.1002/ app.40713.

Orathai, B., Ariffin, A., Rashid, A., Masahiro, O. \& Saowaroj, C. 2010. Effect of polystyrene-modified natural rubber (SNR) on mechanical properties of waste natural rubber latex/ polystyrene blend (WNRL/PS). E-Prints USM 1-4.

Ramarad, S., Khalid, M., Ratnam, C.T., Chuah, A.L. \& Rashmi, W. 2015. Waste tire rubber in polymer blends: A review on the evolution, properties and future. Progress in Materials Science 72: 100-140.
Reddy, N., Reddy, R. \& Jiang, Q. 2015. Crosslinking biopolymers for biomedical applications. Trends in Biotechnology 33(6): 362-369.

Samran, J., Phinyocheep, P., Daniel, P. \& Kittipoom, S. 2005. Hydrogenation of unsaturated rubbers using diimide as a reducing agent. Journal of Applied Polymer Science 95(1): 16-27.

Simma, K., Rempel, G.L. \& Prasassarakich, P. 2009. Improving thermal and ozone stability of skim natural rubber by diimide reduction. Polymer Degradation and Stability 94(11): 1914 1923.

Wideman, L.G. 1984. Heating with Oxidant, Hydrazine and Metal Salt. U.S. Patent 4452950 A.

Wu, W., Zhai, Y., Zhang, Y. \& Ren, W. 2014. Mechanical and microwave absorbing properties of in situ prepared hydrogenated acrylonitrile-butadiene rubber/rare earth acrylate composites. Composites Part B: Engineering 56: 497-503.

Zhang, Y., Liu, Q., Xiang, J. \& Frost, R.L. 2014. Thermal stability and decomposition kinetics of styrene-butadiene rubber nanocomposites filled with different particle sized kaolinites. Applied Clay Science 95: 159-166.

Zolali, A.M. \& Favis, B.D. 2017. Compatibilization and toughening of co-continuous ternary blends via partially wet droplets at the interface. Polymer 114: 277-288.

Pusat Pengajian Sains Kimia dan Teknologi Makanan

Fakulti Sains dan Teknologi

Universiti Kebangsaan Malaysia

43600 UKM Bangi, Selangor Darul Ehsan

Malaysia

*Pengarang untuk surat menyurat; email: sitifairus@ukm.edu.my

Diserahkan: 9 Mac 2017

Diterima: 20 September 2017 